\title{
EKSISTENSI AKAD DALAM TRANSAKSI KEUANGAN SYARIAH
}

\author{
Puspa farida \\ Perbankan Syariah, Fakultas Ekonomi dan Bisnis Islam \\ Puspafarida23@gmail.com
}

\begin{abstract}
ABSTRAK
Abstract: It has been more than two decades since Shari'a Economic Law was intro duced and vastly grew in Indonesia. For that reason, a thourough study is needed to describe the principles, types, and implementation of 'akad' (deal) in this special law. This study reveals that a deal in Shari'a Finance \& Economic Law is consisted of sev eral principles, i.e. balance, fairness, and consensualism that in Islam there is freedom to determine the contract with all the terms and forms of contract desired by the parties, provided that the contract is voluntary and is not included in the prohibition of sharia'. On this basis, the core of the contract which is carried out in Islam is to create benefits for the parties to the agreement for an Islamic financial transactions.
\end{abstract}

Keywords: Contract, Transaction, Islamic Finance

\begin{abstract}
ABSTRAK
Abstrak: Sistem ekonomi dan keuangan Syariah telah diperkenalkan lebih dari dua dekade lamanya di Indonesia. Saat ini, sistem tersebut telah mencapai perkembangan yang luarbiasa. Karena itu, penting kiranya mengkaji prinsip-prinsip, jenis-jenis, dan pelaksanaan akad dari perspektif hukum yang khas ini. Akad adalah ikatan ijab dan kabul yang sesuai dengan hukum syariat yang akibat menimbulkan akibat hukum bagi objek akad .Bahwa dalam islam terdapat kebebasan untuk melakukan akad dengan menentukan segenap syarat dan bentuk akad yang diinginkan oleh para pihak, aasalkan akad tersebut dilakukan secara sukarela serta tidak termasuk dalam larangan syariat. Atas dasar tersebut, inti akad yangdilakukan dalam Islam adalah untuk terciptanya kemaslahatan bagi, para pihak yang melakukan perjanjian untuk sebuah transaksi keuangan syariah.
\end{abstract}

Kata Kunci: Akad, Transaksi, Keuangan Syariah

\section{PENDAHULUAN}

Era globalisasi ekonomi telah menimbulkan kejadian-kejadian baru dalam perkembangan ekonomi dunia, seperti adanya pasar bebas yang menimbulkan persaingan diberbagai bidang usaha yang semakin terbuka, adanya interdependensi sistem, hadirnya lembaga-lembaga keuangan baru dengan pola dan sistem yang berbeda, munculnya sistem transaksi keuangan yang semakin beragam.

Dalam pandangan penulis kontrak merupakan sinonim dari kata perjanjian, sehingga dapat diartikan sebagai peristiwa dimana seorang berjanji kepada orang lain atau dimana dua orang itu saling berjanji untuk melaksanakan suatu hal (Subekti, 1996 : 1)(Ghofur, 2015).

Salam secara etimologis berarti "me nyegerakan atau mendahulukan". Para ulama mazhab memberi definisi salam secara terminologis dengan nuansa yang berbeda walaupun esensinya sama yakni jual beli sesuatu yang ditetapkan sifatnya (namun belum diserahkan) dengan harga kontan.

Islam sebagai agama yang komprehensif memberikan aturan yang jelas mengenai perikatan dan perjanjian untuk dapat diimplementasikan dalam kehidupan. Sejumlah 
prinsip dan dasar-dasar mengenai pengaturan perikatan dan perjanjian tertuang dalam alQur'an dan as-Sunnah yang kemudian dikembangkan oleh para fuqaha sehingga membentuk hukum perjanjian syariah.1 Kemampuan hukum Islam untuk bersosialisasi dalam menghadapi perkembangan zaman dan kebutuhan umat manusia yang senantiasa membutuhkan adanya kepastian hukum merupakan interaksi antara syariat dengan kondisi masyarakat muslim.

Dalam hukum Islam dikenal beberapa istil Dan para ahli hukum Islam klasik juga menggunakan istilah al-iltizam yang umumnya mereka maksudkan sebagai perikatan-perikatan yang timbul dari kehendak sepihak dan kadangkadang perikatan yang timbul dari perjanjian. 4 Sedangkan dalam hukum Islam kontemporer, istilah al-iltizam digunakan untuk menyebut perikatan dan istilah akad digunakan untuk menyebut perjanjian dan bahkan untuk menyebut kontrak ah yang mengandung konsep perikatan, yakni hukm aqd, aldlaman, dan aliltizam. 2 Istilah "hukum akad" sebenarnya tidak lain daripada akibat hukum yang timbul dari suatu perjanjian.

Dilihat dari sumbernya, ahliahli hukum Islam kontemporer, seperti az-Zarqa', menyebut sumber-sumber perikatan (masadir al-iltizam) dalam Islam meliputi lima macam, yaitu : akad (al-'Aqd); kehendak sepihak (alIradah al-Munfaridah); perbuatan merugikan (al-Fi'l ad-Dar); perbuatan bermanfaat (al-Fi'il an-Nafi'); dan syara'.6 Tulisan ini hanya akan mengupas tentang konsepsi perjanjian (al-Aqd) dalam hukum syariah yang merupakan sumber perikatan yang paling penting dalam transaksi keuangan syariah.

\section{PEMBAHASAN}

\section{A. Perjanjian Perikatan Dalam Hukum Islam}

Mengenai perikatan dalam hukum Islam, Anwar memberikan definisi sebagai "terisinya dzimmah seseorang atau suatu pihak dengan suatu hak yang wajib ditunaikannya kepada orang atau pihak lain.”7 Sedangkan az-Zarqa melihatnya sebagai "keadaan di mana seseorang diwajibkan menurut hukum syara untuk melakukan atau tidak melakukan sesuatu bagi kepentingan orang lain".8 Menurut Anwar, hukum akad tambahan menggambarkan konsep perikatan dalam hukum Islam karena di dalamnya terkandung adanya kewajiban dan hak bagi masing-masing pihak.9 Sedangkan azZarqa' melihat hukum akad tambahan di kalangan fuqaha klasik itu merupakan perikatan dalam hukum Barat.(Abdurohman, 2020)

Kedua definisi perikatan tersebut lebih melihat pada obyeknya, yaitu berupa hak dan kewajiban yang timbul pada para pihak yang juga menggambarkan adanya suatu orientasi hukum yang dicirikan oleh semangat objektivisme. Teori ini akan memudahkan lalu lintas kegiatan bisnis modern, karena yang menjadi fokus utama dalam perikatan adalah bukanlah subyek perikatan, akan tetapi obyek perikatan sehingga penggantian subyek atau pemindahan hak-hak perikatan dari suatu subyek ke subyek lain dapat dilakukan dengan mudah. Kebalikan dari teori perikatan obyektif adalah teori perikatan subyektif, yaitu teori yang lebih banyak melihat segi hubungan antar subyek perikatan, yaitu debitur dan kreditur.

Namun demikian, perlu diperhatikan bahwa ulama hukum Islam tidak membuat suatu teori umum tentang perikatan dan menghimpunnya dalam satu tempat kemudian diberi nama perikatan. Hal ini disebabkan karena hukum Islam menggunakan pandangan sintesis mengenai tindakan hukum. Tindakan hukum dilihat secara keseluruhan dengan berbagai syaratnya, dan karenanya kajian hukum Islam dimulai dari tindakan hukum sebagai sumber yang melahirkan akibat hukum. Karena itu, kajian para fuqaha di zaman lampau dimulai dan terpusat pada akad. Jadi, mereka tidak memulai dari akibat hukum, yaitu perikatanperikatan yang lahir dari akad (perjanjian).

Para fuqaha tidak menetapkan hukumhukum masalah fiqhi atas dasar teori umum dan menjelaskan masalah-masalah cabang daripadanya sesuai dengan metode ilmu hukum kontemporer. Mereka mengikuti hukum 
masalah-masalah, rincianrinciannya dan cabang-cabangnya dengan memperhatikan asas-asas umum yang memayunginya. Dengan memperhatikan hukum-hukum cabang, dapat diketahui teori dan dasar-dasarnya. Dalam hukum Islam, sesungguhnya terdapat sejumlah hubungan hukum yang dapat dikategorikan sebagai perikatan, akan tetapi para fuqaha tidak menghimpun dan menyatukannya dalam suatu asas umum. Oleh karena itu, para ahli hukum Islam kontemporer mencoba menghimpun berbagai hukum dan memberinya nama dengan al-Iltizam yang merupakan padanan dari istilah perikatan dalam hukum Barat.

Mengenai proses terjadinya suatu perikatan, Abdoerraoef mengemukakan tiga tahapan, yaitu pertama perjanjian, yaitu pernyataan dari seseorang untuk melakukan sesuatu atau tidak melakukan sesuatu dan tidak ada sangkut pautnya dengan kemauan orang lain. Kedua, persetujuan, yaitu pernyataan setuju dari pihak kedua untuk melakukan sesuatu atau tidak melakukan sesuatu sebagai reaksi terhadap janji yang dinyatakan oleh pihak pertama. Ketiga, apabila dua buah janji dilaksanakan maksudnya oleh para pihak, maka terjadilah apa yang dinamakan akad. Maka yang mengikat masing-masing pihak sesudah pelaksanaan perjanjian bukan lagi perjanjian atau al-ahdu tetapi al-aqdu.(v. M. buyanov, 1967)

Proses perikatan ini tidak terlalu berbeda dengan proses perikatan yang dikemukakan oleh Subekti yang didasarkan pada KUH Perdata. Menurutnya, perikatan adalah suatu perhubungan hukum antara dua orang atau dua pihak berdasarkan mana pihak yang satu berhak menuntut sesuatu hal dari pihak yang lain, dan pihak yang lain berkewajiban untuk memenuhi tuntutan itu. Sedangkan pengertian perjanjian adalah suatu peristiwa di mana seseorang berjanji kepada orang lain atau di mana dua orang itu saling berjanji untuk melaksanakan sesuatu hal. Peristiwa perjanjian ini merupakan asas umum yang terdapat dalam akad. Kedudukan akad dalam fiqh muamalah adalah penting ditinjau dari fungsi dan pengaruhnya sehingga suatu aktifitas muamalah dapat dikatakan sah jika akad yang dilaksanakan itu terpenuhi syarat dan rukunnya. Dalam hukum
Islam untuk sahnya suatu perjanjian haruslah terpenuhi rukun dan syarat perjanjian (akad).

\section{B. Akad Dalam Hukum Islam}

Al-'Aqd berasal dari kata 'aqada ya'qidu - 'aqdan; jamaknya adalah al-'uqûd. Secara bahasa al-'aqd bermakna ar-rabth (ikatan), asy-syadd (pengencangan), attaqwiyah (penguatan). Jika dikatakan, 'aqada al-habla (mengikat tali), maksudnya adalah mengikat tali satu dengan yang lain, mengencangkan dan menguatkan ikatannya. Al-'aqdu juga bisa bermakna al-'ahdu (janji) atau al mîtsâq (perjanjian). Adapun al-'uqdah (jamaknya al-'uqad) adalah obyek ikatan atau sebutan untuk sesuatu yang diikat. Pada awalnya kata 'aqada digunakan untuk benda padat seperti tali dan bangunan, namun kemudian dengan majaz isti'ârah kata ini juga diterapkan untuk selainnya seperti: 'aqd al-bay' (akad jual-beli), 'aqd al- 'ahd (akad perjanjian), 'aqd an-nikâh (akad nikah). Dalam konteks ini, 'aqada dimaknai sebagai ilzâm (pengharusan) dan iltizâm (komitmen) atau irtibâth (pertautan).

Al-'aqd, meski asalnya secara bahasa bermakna asy-syadd secara syar' $i$ menjadi keterikatan atau pertautan ijab dengan qabul, seperti akad jual-beli, nikah dan sebagainya." Az-Zuhaili memberi definisi akad dengan makna pertemuan ijab dan qabul yang dibenarkan oleh syara' yang menimbulkan akibat hukum terhadap obyeknya. Hal senada dikemukakan oleh Anwar, bahwa akad adalah pertemuan ijab dan qabul sebagai pernyataan kehendak dua pihak atau lebih untuk melahirkan suatu akibat hukum pada obyeknya.

Dalam buku Qawâ'id al-Fiqh dinyatakan, "al-'Aqd menurut fuqaha adalah keterikatan bagian-bagian tasharruf secara syar'i dengan ijab dan qabul; atau al-'aqd merupakan keterikatan atau komitmen dua pihak yang berakad dan kesengajaan keduanya atas suatu perkara. Dengan demikian, al-'aqd merupakan ungkapan mengenai keterikatan ijab dan qabul.Ijab (offer) dan qabul (acceptance) merupakan unsur terpenting dari 
suatu akad karena dengan adanya ijab dan qabul maka terbentuklah suatu akad (contract).

Definisi ini bersifat lebih khusus karena terdapat pengertian akad secara istilah yang lebih luas dari pengertian ini. Namun ketika berbicara mengenai akad, pada umumnya pengertian inilah yang paling luas dipakai oleh para fuqaha. Adapun pengertian akad yang bersifat lebih umum mencakup segala diinginkan orang untuk dilakukan, baik itu yang muncul karena kehendak sendiri (irâdah munfaridah), seperti: wakaf, perceraian dan sumpah maupun yang memerlukan dua kehendak (irâdatain) untuk mewujudkannya, seperti: buyu (jualbeli), sewa-menyewa, wakâlah (perwakilan) dan rahn (gadai).

Dari pengertian akad yang lebih umum ini muncul sedikit perbedaan dengan akad yang dipahami oleh fuqaha dan ahli-ahli hukum perdata. Perbedaannya adalah bahwa dalam pengertian yang lebih luas mencakup kehendak tunggal dapat melazimkan suatu transaksi, sementara menurut undang-undang hukum perdata, akad mesti melibatkan dua kehendak. Karena itu wilayah akad dalam pengertian umum jauh lebih luas dibandingkan dengan akad dalam pengertian khusus.

Dikalangan fuqaha terdapat perbedaan pendapat mengenai unsur pembentuk tersebut yang terdiri dari rukun dan syarat. Dengan rukun, menurut mazhab jumhur (Maliki, Syafi'i dan Hambali), dimaksudkan sebagai unsurunsur yang membentuk akad, yang dalam hal ini adalah : 1. Al-'Aqidain, yaitu para pihak yang terlibat langsung dengan akad 2. Mahallul aqad, yaitu obyek akad atau sesuatu yang hendak diakadkan 3. Shigat aqad, pernyataan kalimat akad berupa ijab dan qabul.

Kemudian syarat akad secara umum dapat dibagi menjadi dua macam, yaitu :

1. Syarat adanya (terbentuknya) akad, di mana apabila syarat ini tidak terpenuhi akad tidak ada atau tidak terbentuk dan akadnya disebut batal

2. Syarat sahnya akad, yaitu syarat dimana apabila tidak terpenuhi tidak berarti akad tidak ada atau tidak terbentuk. Bisa saja akadnya ada dan telah terbentuk karena syarat terbentuknya telah terpenuhi misalnya, hanya saja akad dianggap belum sempurna dan masih memiliki kekurangan dan dalam keadaan demikian akad tersebut ahli-ahli hokum.

Satu kelompok, walaupun ada perbedaan-perbedaan antara satu dengan yang lain. Mengenai pengelompokan jenis-jenis akad ini banyak variasi penggolongannya. Para fuqaha mengemukakan bahwa akad dapat diklassifikasikan dalam berbagai segi,32 di antaranya adalah apakah akad itu diperbolehkan oleh syara' atau tidak; apakah akad itu bernama atau tidak; apakah akad itu mengikat atau tidak; dengan melihat kepada bentuk dan cara melakukan akad; tujuan diselenggarakannya akad.

\section{Unsur dan Klassifikasi Akad Perjanjian}

Syarat-syarat adanya (syurut al-in'iqad) itu meliputi tujuh macam sebagai berikut : (1) bertemunya ijab dan kabul (adanya kata sepakat antara para pihak), (2) bersatunya majlis akad, (3) berbilangnya para pihak, (4) berakal/tamyiz, (5) obyek akad dapat diserahkan, (6) obyek akad ditentukan, dan (7) obyek dapat ditransaksikan atau dapat menerima hukum akad (mutaqawwim). Sedangkan syaratsyarat sahnya ada lima macam, yaitu (1) tidak ada paksaan, (2) tidak menimbulkan kerugian (darar), (3) tidak mengandung ketidakjelasan (garar), (4) tidak mengandung riba, dan (5) tidak mengandung syarat fasid.

Dari segi kekuatan hukumnya, akad tersebut dapat diurutkan menjadi lima jenjang dari yang paling lemah kepada yang paling kuat, yaitu (1) akad batil, (2) akad fasid, (3) akad mauquf, (4) akad nafiz, (5) akad lazim. Dua yang pertama termasuk kategori akad yang tidak sah dan tiga macam terakhir termasuk kategori akad yang sah. Akad secara garis besar berbeda satu dengan yang lainnya. Hal ini berdasarkan asas, tujuan, ketentuan, sifat dan hukum-hukum yang ada dalam akad-akad itu sendiri. Dalam kitab-kitab fiqhi terdapat banyak bentuk-bentuk akad yang kemudian dapat dikelompokkan dalam berbagai variasi jenisjenis akad. Masing-masing golongan akad 
kadang-kadang dikumpulkan dalam empat prinsip dalam perikatan secara syariah yang perlu diperhatikan, yaitu:36 1. Tidak semua akad bersifat mengikat kedua belah pihak (aqad lazim), karena ada kontrak yang hanya mengikat satu pihak (aqad jaiz). 2. Dalam melaksanakan akad harus dipertimbangkan tanggung jawab yang berkaitan dengan kepercayaan yang diberikan kepada pihak yang dianggap memenuhi syarat untuk memegang kepercayaan secara penuh. 3. Larangan mempertukarkan kewajiban (dayn) melalui .

Transaksi penjualan sehingga menimbulkan kewajiban (dayn) baru atau yang disebut bay' al-dayn bi aldayn. 4. Akad yang berbeda menurut tingkat kewajiban yang masih bersifat janji (wa'd) dengan tingkat kew Pada prinsipnya, akad-akad perjanjian syariah seharusnya mengandung azas-azas hukum perikatan Islam yang meliputi, pertama, azas kebebasan. Para pihak yang berakad bebas untuk melakukan bentuk perikatan dan perjanjian, baik substansi dan meterinya maupun syarat-syarat yang dipersyaratkan dalam klausul perjanjian. kedua, azas persamaan. Yaitu kedua belah pihak ajiban yang berupa sumpah (ahd).

Memiliki kedudukan yang sama saat menentukan hak dan kewajiban masing-masing pihak.37 ketiga, azas keadilan. Yaitu keadilan proporsional dalam konteks perjanjian yang menekankan pada kesetaraan posisi dan pertukaran prestasi di antara para pihak yang berkontrak. Keadilan proporsional ini diwujudkan dalam bentuk equal pay for equal work, yaitu masing-masing pihak akan mendapatkan bagian masing-masing sesuai dengan konstribusinya.38 keempat, asas kerelaan atau konsensualisme.39 Al-Qur'an dan hadis menekankan bahwa hendaknya transaksi itu didasari atas kerelaan dan keridhaan dari masing-masing pihak yang bertransaksi. kelima, asas kejujuran dan kebenaran.40 Salah satu unsur etika dalam berbisnis adalah pentingnya kejujuran dan kebenaran. Nilai ini seharusnya menjadi landasan aplikatif bagi lembaga keuangan yang berlabelkan Islam. Karena unsur kejujuran dan kebenaran akan menghindarkan pihak-pihak yang berkontrak dari segala bentuk manipulasi dan kecurangan. keenam, asas manfaat. Dan ketujuh, asas tertulis41 perjanjian-perjanjian yang dilakukan seharusnya dituangkan dalam tulisan yang dapat dipertanggungjwabkan secara hukum. Pembuktian akibat terjadinya wanprestasi dari masing-masing pihak dapat dibuktikan secara yuridis apabila ada bukti tertulis. Asas-asas perjanjian tersebut dirumuskan berdasarkan pemahaman terhadap nas al-Qur'an dan sunah Nabi saw, juga dirumuskan dari itu meliputi penipuan berbentuk perbuatan dan ucapan. Sehingga apabila terjadi penipuan dan manipulasi terhadap obyek akad, maka suatu perjanjian dapat dibatalkan.

\section{Akad Dalam Transaksi Keuangan Syariah}

Pandangan Islam tentang akad sebenarnya tidak ada batasan yang ketat tentang bagaimana perjanjian tersebut dibentuk. Beberapa pembatasan yang ada dalam kitab fiqhi klasik sebenarnya sebagian besar adalah cakupan dari beberapa bentuk perjanjian yang ada pada masa kitab tersebut disusun. Walaupun banyak kitabkitab fiqh yang membatasi pembahasan akad dengan membahas bentuk-bentuk tertentu dari akad, namun pembahasan tersebut sebenarnya pembahasan secara sekilas tentang hukum perjanjian dalam Islam yang ditetapkan oleh para fuqaha. Penyebutan bentuk-bentuk akad oleh para fuqaha adalah berdasarkan akad yang umum berlaku pada masanya. Jika peradaban semakin maju, maka tidak menutup kemungkinan untuk mengembangkan bentukbentuk akad.43 Jadi pengembangan macam dan bentuk akad selanjutnya tidak ada larangan. Keberadaan akad dapat ditelaah dengan melihat beberapa kaedah atau prinsip utama hukum muamalah dalam Islam, diantaranya, pertama, pada dasarnya segala bentuk muamalah adalah boleh kecuali yang ditentukan selain dari alQur'an dan Sunnah. Kedua, muamalah dilakukan atas dasar sukarela tanpa mengandung. (Kristianto, 2012) 
Pandangan Islam tentang akad sebenarnya tidak ada batasan yang ketat tentang bagaimana perjanjian tersebut dibentuk. Beberapa pembatasan yang ada dalam kitab fiqhi klasik sebenarnya sebagian besar adalah cakupan dari beberapa bentuk perjanjian yang ada pada masa kitab tersebut disusun. Walaupun banyak kitabkitab fiqh yang membatasi pembahasan akad dengan membahas bentuk-bentuk tertentu dari akad, namun pembahasan tersebut sebenarnya pembahasan secara sekilas tentang hukum perjanjian dalam Islam yang ditetapkan oleh para fuqaha. Penyebutan bentuk-bentuk akad oleh para fuqaha adalah berdasarkan akad yang umum berlaku pada masanya. Jika peradaban semakin maju, maka tidak menutup kemungkinan untuk mengembangkan bentukbentuk akad.43 Jadi pengembangan macam dan bentuk akad selanjutnya tidak ada larangan. Keberadaan akad dapat ditelaah dengan melihat beberapa kaedah atau prinsip utama hukum muamalah dalam Islam, diantaranya, pertama, pada dasarnya segala bentuk muamalah adalah boleh kecuali yang ditentukan selain dari alQur'an dan Sunnah. Kedua, muamalah dilakukan atas dasar sukarela tanpa mengandung kesesuaian antara keduanya untuk memunculkan kelaziman (kewajiban) yang bersifat syar'i pada kedua pihak, yang diindikasikan dari adanya suatu ungkapan, tulisan, isyarat atau tindakan. Dengan demikian dapat dipahami bahwa esensi akad adalah pencapaian kesepakatan kedua belah pihak, di mana suatu perbuatan seseorang dianggap sebagai suatu pernyataan kehendak. Dalam akad, pernyataan kehendak dapat dilakukan berupa tindakan yang menurut kebiasaan dianggap sebagai akad. Tindakan tersebut juga dianggap sebagai pernyataan kerelaan atas suatu persyaratan dari suatu pihak. Suatu kebiasaan selama tidak melanggar syara' adalah dibolehkan dan dapat diambil sebagai dasar hukum. Karena sesungguhnya hukum asal dalam bermuamalah adalah boleh dan tidak diberikan penjelasan dalam melaksanakannya, maka untuk pelaksanaannya wajib dikembalikan kepada kebiasaan yang telah berlaku. Modifikasi dalam bidang muamalah sangat dimungkinkan karena pada dasarnya tidaklah ada syariat yang bersifat absolut, mutlak dan berlaku untuk segala waktu, tempat, dan keadaan. Dalam hukum Islam terdapat maqasid asy-syari'ah yang berisi maksud atau tujuan dari disyariatkan hal tersebut. Guna mencapai tujuan itu, syariat Islam ada yang bersifat dinamis dalam artian dapat berubah sesuai kebutuhan sosial atau kontekstual. Modifikasi sebenarnya tidak akan melanggar prinsip-prinsip hukum Islam dalam proses transformasi dalam bentuk peraturan bank Indonesia.

\section{E. Asas-asas Akad (Perjanjian) dalam Hukum Ekonomi Syariah}

Seperti telah dimaklumi, bahwa sistem hukum merupakan keseluruhan aturan hukum yang disusun secara terpadu berdasarkan asasasas tertentu. Sebagai suatu sistem, hukum terdiri dari sub-sub sistem yang satu sama lain berkaitan dalam hubungan yang seimbang,dan serasi tidak tumpang tindih,tidak berbenturan karena asas-asasnya yang terpadu. sas-asas yang terdapat dalam hukum perdata harus senada, seirama dengan asas yang terdapat dalam Hukum Nasional, demikian juga dengan asas-asas hukum perjanjian harus senada dengan asas-asas hukum Perdata (Mariam Darus Badrulzaman, 1994: 15)

Sistem hukum Islam merupakan keseluruhan aturan hukum yang disusun secara terpadu berdasarkan asas-asas tertentu. Sistem hukum Islam terdiri dari sub-sub sistem yang satu sama lain berkaitan dalam hubungan yang seimbang. Ahli hukum Islam klasik membuat perjenjangan norma-norma hukum Islam menjadi dua tingkat, yaitu (1) al-ushul (asasasas umum), dan (2) al-furu'(peraturanperaturan hukum kongkrit). Al-ushul (asas-asas umum) meliputi kategori yang luas sehingga mencakup juga norma norma filosofis dasar yang menjadi tegaknya kedua norma diatas ( $S$. Anwar: 2007, 12-14). Selanjutnya Syamsul Anwar mengemukakan bahwa norma-norma hukum Islam dapat dijenjangkan menjadi tiga lapis, yaitu: (1) Nilai nilai dasar atau norma filosofis (al-qiyam al asasiyyah); (2) Asasasas umum (al-ushul al kulliyyah), dan (3) 
Peraturan-peraturan hukum konkret (al-ahkam al-far'iyyah).

Peraturan hukum konkret adalah konkretisasi dari asas umum dan terwujud baik dalam ketentuan-ketentuan hukum taklifi seperti halal, haram, wajib, sunah dan mubah maupun dalam ketentuan-ketentuan hukum wadh'i yang meliputi sebab, syarat dan halangan. Ketiga lapisan norma ini tersusun secara hierarkis. Norma yang abstrak dikonkretisasi dalam norma yang lebih konkret. Nilai-nilai dasar dikonkretisasi dalam normanorma antara baik berupa asas-asas hukum Islam (an-nazhariyyah al-fiqhiyyah) maupun berupa kaidah-kaidah hukum Islam (al-qawaid al-fiqhiyyah). Norma-norma tengah (asas-asas umum) hukum Islam dikonkretkan lagi dalam bentuk-bentuk peraturan peratuan hukum konkret (al-ahkam al-far'iyyah). Asas-asas perjanjian merupakan konkretisasi dari normanorma filosofis, yaitu nilai nilai dasar yang menjadi fondasi ajaran Islam. Asas-asas perjanjian dalam hukum Islam terdiri dari asas kebolehan (mabda' al-ibahah), asas kebebasan berkontrak (mabda' hurriyyah at ta'aqud), asas konsensualisme/kesepakatan (mabda' arradha'iyyah) asas janji itu mengikat, asas keseimbangan (mabda' at-tawazun fi al mu'awadhah), asas kemaslahatan (tidak memberatkan), asas amanah dan asas keadilan. Asas ibahah atau kebolehan merupakan asas umum hukum Islam dalam bidang muamalat yang dirumuskan pada kalimat "pada dasarnya segala sesuatu itu boleh dilakukan sampai ada dalil yang melarangnya". Hal ini bertolak belakang dengan asas yang berlaku dalam ibadah bahwa tidak ada ibadah kecuali apa yang telah dicontohkan oleh Rosulullah Saw. Jika dihubungkan dengan tindakan hukum dan perjanjian maka perjanjian apa pun dapat dibuat sejauh tidak ada larangan khusus mengenai perjanjian tersebut. Asas kebebasan berakad dalam hukum Is lam dibatasi dengan larangan makan harta sesama dengan jalan bathil (Q.S. 4:29). Yang dimaksud dengan makan harta sesama dengan jalan bathil adalah makan harta orang lain dengan cara yang tidak dibenarkan dan tidak sah menurut hukum Syariah. Asas kosensual berlandaskan pada kaidah hukum
Islam pada asasnya perjanjian (akad) itu adalah kesepakatan para pihak dan akibat hukumnya adalah apa yang mereka tetapkan melalui janji. Asas janji itu mengikat berlandaskan pada perintah dalam Al Qur' an agar memenuhi janji. Dalam kaidah ushul fikih, perintah itu pada asasnya menunjukkan wajib. Di antara ayat dan hadits dimaksud adalah, ....dan penuhilah janji, sesungguhnya janji itu akan dimintakan pertanggungjawabannya (Q.S.17:34). Hukum perjanjian Islam menekankan perlunya keseimbangan dalam perjanjian. Keseimbangan ini dapat berupa keseimbangan antara yang diberikan dengan yang diterima maupun keseimbangan dalam memikul risiko.

Asas kemaslahatan dimaksudkan agar akad yang dibuat oleh para pihak bertujuan untuk mewujudkan kemaslahatan bagi mereka dan tidak boleh menimbulkan kerugian (mudharat) atau keadaan yang memberatkan (masyaqqah). Asas amanah mengandung arti bahwa para pihak yang melakukan akad harus memiliki itikad baik dalam bertransaksi dengan pihak lainnya.Dalam perjanjian Islam dituntut adanya amanah misalnya memegang rahasia, atau memberikan informasi yang sesungguhnya, tidak bohong. Dalam hukum Islam keadilan merupakan perintah Allah yang tertera dalam Al Qur'an, berlaku adillah, karena adil itu lebih dekat dengan takwa (Q.S. 5:8). Keadilan merupakan tujuan yang hendak diwujudkan oleh semua hukum. Jenis Akad dan Implementasi pada Usaha Bank Syariah Lembaga keuangan merupakan financial intermediary (lembaga perantara keuangan) uang berfungsi menghimpun dan menyalurkan dana kepada masyarakat. Lembaga keuangan terdiri dari Lembaga Keuangan Bank (LKB) dan Lembaga Keuangan Bukan Bank (LKBB).

Banyak produk atau jasa yang ditawarkan oleh bank maupun lembaga keuangan bukan bank kepada masyarakat. Bank syariah sama halnya dengan bank konvensional berfungsi sebagai intermediary in stitution namun jasa yang ditawarkan bank syariah kepada masyarakat bukan saja jasa yang dapat diberikan oleh suatu bank konvensional (commer cial bank), melainkan juga jasa-jasa 
yang biasanya diberikan oleh suatu lembagaLembaga konvensional modern (multi finance company). Hal ini karena beragamnya akad (perjanjian) yang dapat digunakan dalam transaksi tersebut.

Berkaitan dengan akad yang digunakan dalam Lembaga Keuangan Syariah, hasil musyawarah (ijma Internasional) para ahli ekonomi Muslim beserta dan para ahli fiqih dan academi Fiqih di Mekah pada tahun 1973, menyimpulkan bahwa konsep dasar hubungan ekonomi berdasarkan syariah Islam dalam sistem ekonomi Islam dapat diterapkan dalam operasional lembaga keuangan bank maupun lembaga keuangan bukan bank (Muhammad, 2002: 35-50) Secara garis besar, hubungan ekonomi berdasarkan syariah Islam ditentukan oleh hubungan akad yang terdiri dari lima konsep akad. Bersumber dari kelima konsep dasar inilah dapat ditemukan jenis jenis akad yang dapat digunakan dalam usaha lembaga keuangan bank syariah dan lembaga keuangan bukan bank syariah untuk dioperasionalkan. Kelima konsep tersebut adalah :
1) Prinsip simpanan
2) Prinsip bagi hasil
3) Prinsip jual beli
4) Prinsip sewa
5) Prinsip jasa.

Prinsip simpanan murni merupakan fasilitas yang diberikan oleh Bank Islam yang memberikan kesempatan kepada pihak yang kelebihan dana untuk menyimpan dananya dalam bentuk wadi'ah. Akad wadi'ah dapat biasa diberikan untuk tujuan investasi guna mendapatkan keuntungan seperti halnya tabungan dan deposito. Dalam dunia perbankan konvensional al-wadi'ah identik dengan giro. Sistem ini adalah suatu sistem yang meliputi tatacara pembagian hasil usaha antara penyedia dana dengan pengelola dana. Pembagian hasil usaha ini dapat terjadi antara bank dengan penyimpanan dana maupun antara bank dengan nasabah penerima dana. Bentuk produk yang berdasarkan prinsip ini adalah akad mudharabah dan akad musyarakah. Lebih jauh mudharabah dapat dipergunakan sebagai dasar baik untuk produk pendanaan (tabungan dan deposito) maupun pembiayaan, sementara musyarakah lebih banyak untuk pembiayaan. Akad mudharabah ini selain digunakan dalam perbankan syariah juga digunakan dalam asuransi syariah. Dana yang terkumpul dari nasabah perusahaan asuransi syariah (premi) diinvestasikan berdasarkan syariah dengan sistem bagi hasil (mudharabah). Sedangkan pada asuransi konvensional investasi dana dilakukan ke lembaga keuangan yang menggunakan bunga. Prinsip ini merupakan suatu sistem yang menerapkan tata cara jual beli, di mana bank atau LKBB akan membeli terlebih dahulu barang yang dibutuhkan atau mengangkat nasabah sebagai agen bank melakukan pembelian barang atas nama bank, kemudian bank menjual barang tersebut kepada nasabah dengan harga beli ditambah keuntungan (margin). Prinsip ini bisa digunakan bank atau lembaga keuangan lainnya seperti BMT.Akad yang digunakan adalah akad bai bistaman 'ajil atau akad murabahah. Prinsip ini secara garis besar terbagi menjadi dua jenis, (1) Ijarah, sewa murni, seperti halnya penyewaan traktor dan alat-alat produk lainnya (operating lease). Dalam teknis perbankan, bank dapat membeli dahulu equipment yang dibutuhkan nasabah kemudian menyewakan dalam waktu dan harga yang telah disepakati kepada nasabah; (2) bai al takjiri atau ijarah al muntahiyah bit tamlik merupakan penggabungan sewa dan beli, dimana si penyewa mempunyai hak untuk memiliki barang pada akhir masa sewa (financial lease).

Prinsip ini meliputi seluruh layanan nonpembiayaan yang diberikan bank. Bentuk produk yang berdasarkan prinsip ini antara lain bank garansi, kliring, inkaso, jasa transfer, pembayaran rekening telepon, listrik, dan lainlain. Secara Syari'ah prinsip ini didasarkan pada konsep al ajr wal umula Konsep akad tersebut diimplementasikan pada bank syariah, sesuai dengan tiga usaha pokok bank, yaitu dalam hal penghimpunan dana, penyaluran dana, dan pemberian jasa dalam lalu lintas pembayaran. Untuk lebih jelasnya dapat dilihat dalam Tabel 1. Dasar Hukum akad -akad tersebut terdapat dalam UU No.21 tahun 2008, tentang Bank Syariah, berbagai Fatwa Dewan Syariah Nasional MUI, dan Berbagai Peraturan 
Bank Indonesia (PBI). Dengan menggunakan akad tersebut, maka jenis usaha yang ditawarkan oleh Bank Syariah lebih beragam dibandingkan dengan jenis usaha yang ditawarkan oleh Bank Konvensional. Untuk Bank Konvensional hal ini seperti yang diatur dalam UU No.10 Tahun 1998, tentang Perbankan. Sedangkan untuk Bank Syariah diatur dalam UU NO.21 tahun2008, tentang Bank Syariah, untuk lebih jelasnya dilihat dalam Tabel 2.h.

\section{F. Prinsip jual beli (tijârah)}

Yang diplikasikan dengan menggunakan akad sebagai berikut:

a. Murâbahah Murâbahah yaitu usaha yang dilakukan dengan melakukan transaksi jual beli dengan memperoleh margin keuntungan (mark-up). 3 Transaksi ini dapat dilakukan dengan cara pihak pertama membelikan barang yang diajukan pihak kedua. Pihak pertama menjualnya kepada pihak kedua dengan meminta keuntungan (mark-up), sedangkan pihak kedua membayar barang tersebut kepada pihak pertama, bisa dengan sistem angsuran yang lamanya telah ditentukan dan disepakati kedua belah pihak.

b. Jual beli salam Salam secara etimologis berarti "me nyegerakan atau mendahulukan". Para ulama mazhab memberi definisi salam secara terminologis dengan nuansa yang berbeda walaupun esensinya sama yakni jual beli sesuatu yang ditetapkan sifatnya (namun belum diserahkan) dengan harga kontan.4 Akad jual beli salam ditetapkan berdasarkan Alquran Q.s. al-Baqarah [2]: 282 , hadis nabi mengenai ketentuan akad salam, serta ijmak ulama tentang dibolehkannya akad salam. Salam merupakan akad yang termasuk bagian dari jual beli. Oleh karena itu, semua rukun dan syarat jual beli juga menjadi rukun dan syarat sala syarat tambahan pada jual beli salam yakni harus dipenuhi syarat-syarat yang berkaitan dengan modal dan juga syarat yang berkaitan dengan barang yang dibeli atau dipesan.

\section{G. Jual beli istisnâ}

Istisnâ merupakan kontrak penjualan antara pembeli dan pembuat barang, pembuat barang berusaha memalui orang lain untuk membuat atau membeli barang menurut spesifikasi seperti yang telah disepakati, dan menjualnya kepada pembeli akhir. Menurut jumhur ulama, jual beli istisnâ merupakan jenis khusus dari jual beli salam sehingga ketentuan istisnâ mengikuti ketentuan salam meskipun sebagaian ulama mazhab melarang jual beli ini. Namun sebagian fuqahâ kontemporer berpendapat bahwa istisnâ adalah sah atas dasar qiyâs dan aturan umum syariah karena itu memang jual beli biasa dan penjual akan mampu menyerahkan barang pada saat penyerahan.

Transaksi yang berprinsip pada akad kerjasama

1) Mudhârabah Akad mudhârabah merupakan suatu akad kerjasama antara dua orang atau lebih dalam suatu usaha. Salah satu di antara mereka merupakan pemodal dan yang lain merupakan pihak yang akan memutar, atau mengatur modal dengan usaha dan waktu yang dimilikinya. Prinsip akad mudhârabah berdasar pada sistem bagi hasil, sehingga jika dalam usaha yang disepakati tersebut nantinya mengalami keuntungan maka akan dibagi menurut besaran yang telah disepakati kedua belah pihak (margin yang telah disepakati).7 Jika terjadi kerugian, maka kerugian tersebut akan ditanggung sepenuhnya oleh pemilik dana, sedangkan pengusaha,menanggung kerugian tersebut dengan usaha yang telah dilakukan.

Dalam kaitannya dengan pekerjaan, atau usaha yang dilakukan oleh pengusaha, mudhârabah dapat dibedakan menjadi akad mudhârabah muthlaqah dan akad mudhârabah muqayyadah. Dalam akad mudhârabah muthlaqa mengaplikasikannya dengan memberikan dana pada suatu usaha yang telah ada, 
yakni dengan ketentuan adanya kejelasan nisbah bagi hasil yang akan diperoleh masingmasing pihak. c. Muzâra'ah dan Musâqah Muzâra'ah adalah kerjasama dalam mengelola pertanian antara pemilik lahan dan penggarap, di mana pemilik lahan memberikan lahan pertanian kepada si penggarap untuk ditanami. Sedangkan imbalan bagi penggarap ialah bagian tertentu dari hail panen.12 Muzâra'ah sering dikaitkan dengan mukhâbarah, tetapi di antara keduanya terdapat perbedaan; jika muzâra'ah, benih dari pemilik lahan, sedangkan mukhâbarah benih berasal dari penggarap.13 Sedangkan musâqah ialah suatu akad penyerahan pohon kepada orang yang menyiramnya (mengurusnya) dan menjanjikan pada orang tersebut bahwa ia akan diberi imbalan dari hasil yang diperoleh dalam jumlah tertentu. Akad ini merupakan persekutuan perkebunan untuk mengembangkan tanaman, di mana pohon berada pada pihak lain dan dengan perjanjian bahwa buah yang dihasilkan untuk dibagi kedua belah pihak, dengan presentasi yang mereka sepakati.h, pemberi modal menyerahkan modalnya kepada pengusaha untuk dipakai dalam usaha apapun, tidak dibatasi jenis dan tempatnya, sehingga dalam akad ini pekerjaan atau Adapun dalam akad mudhârabah muqayyadah, pemilik modal memberikan modalnya kepada seseorang untuk dipakai dalam usaha yang telah ditentukan. Dalam mengaplikasikan akad ini, bank syariah dapat memberikan dana investasi kepada pengusaha dengan kejelasan jenis usaha, jumlah dana dan nisbah bagi hasil yang kesemuanya berdasarkan kontrak yang telah disepakati. b. Musyârakah Akad yang berprinsip pada sistem bagi hasil yakni musyârakah, yaitu akad kerjasama antar dua orang atau lebih untuk usaha tertentu, yang masing-masing menanamkan modal pada usaha tersebut atau dengan prinsip usaha patungan.9 Para ulama mazhab sependapat akan kebolehannya.10 Akad musyârakah juga berprinsip pada mekanisme bagi hasil, sehingga jika dalam usaha yang dilakukan mendapatkan keuntungan dan kerugian, maka akan dibagi berdasarkan besar dana masing-masing pihak yang diinvestasikan dalam usaha.11 Dalam transaksi ini, lembaga keuangan syariah dapat bidang usaha yang akan dilakukan oleh pengusaha bersifat mutlak.

Akad muzâra'ah dan musâqah sebagai suatu bentuk persarikatan di bidang pertanian memiliki prospek yang cukup baik, karena akad ini lebih sesuai dengan kondisi Indonesia yang agraris dan sebagian besar penduduknya berusaha di bidang pertanian. Meskipun sampai saat ini, investasi pada bidang pertanian dianggap memiliki risiko yang cukup tinggi namun keuntungannya kecil.

2) Akad-akad muamalah yang berprinsip sewa (ijârah), sebagai berikut: a. Ijârah Akad ijârah, ialah akad pemindahan hak guna (manfaat) atas suatu barang atau jasa dalam waktu tertentu melalui pembayaran sewa/upah, tanpa diikuti dengan pemindahan kepemilikan barang itu sendiri. 15 Dalam Fatwa DSN sebagaimana dikutip di atas, ijârah diartikan sebagai akad sewa menyewa yang menjadi prinsip syariah dalam pembiayaan yang dilakukan oleh bank, yakni dalam penyediakan uang atau tagihan yang dipersamakan dengan itu, berdasarkan persetujuan atau kesepakatan antara bank dengan pihak lain, yang mewajibkan pihak yang dibiayai untuk mengembalikan uang atau tagihan tersebut setelah jangka waktu tertentu dengan imbalan/bagi hasil. Prinsip syariah yang digunakan di atas, diterapkan pada bank syariah dengan prinsip sewa murni (ijârah) atau dengan pilihan pemindahan kepemilikan atas barang yang disewa dari pihak bank pada pihak yang menyewa setelah selesai masa sewa (ijârah wa iqtinâ/ijârah muntahiyah bi al-tamlîk). Model transaksi ijârah dan pembiayaan ijârah di kalangan dunia usaha sering dianggap sama dan serupa dengan leasing sehingga sering menimbulkan kerancuan bahwa bank 
syariah menggunakan transaksi leasing. Agar tidak timbul kerancuan tersebut, sebagian pakar berpendapat bahwa perbedaan antara pembiayaan ijârah dan leasing terletak pada tujuannya. Jika pembiayaan ijârah bertujuan untuk menyediakan dana, sedangkan leasing bertujuan menyediakan barang modal. Tetapi hal ini masih dapat diperdebatkan lebih lanjut.16

3) Akad muamalah yang berprinsip pada penyediaan jasa ('ujr) Di samping akad dan prinsip disebutkan di atas, dalam konsep ekonomi Islam terdapat akadakad lain yang dapat dikembangan serta diaplikasikan masyarakat dalam bermuamalah, yakni, akad wakâlah, kafâlah, hawâlah dan lainnya.

Agar lebih jelasnya pembahasan mengenai prinsip jasa tersebut, serta sumber syar'i yang melandasinya, di bawah ini akan dijelaskan secara singkat sebagai berikut:

- Wakâlah yakni akad pelimpahan kekuasaan oleh satu pihak kepada pihak lain dalam hal-hal yang boleh untuk diwakilkan.17 Terdapat perbedaan pendapat di kalangan ulama mazhab mengenai rukun wakâlah. Pendapat yang umum yakni pendapat sebagian besar ulama bahwa rukun wakâlah ada empat yakni muawakkil, wâkil, muwakkal fih, shigah ijâb qabûl. Akad wakâlah dapat dilakukan secara langsung tanpa dikaitkan dengan keadaan tertentu maupun dengan suatu keadaan atau masa yang akan e. datang. Wakâlah yang secara langsung disebut wakâlah tanjîz, sedangkan yang dikaitkan dengan keadaan tertentu disebut wakâlah ta'li .

- Kafâlah, merupakan akad yang berhubungan dengan penjamin dan jaminan. Secara jelas akad kafâlah ialah akad jaminan yang diberikan oleh penanggung (kafîl) kepada pihak ketiga untuk me menuhi kewajiban hawâlah, para ulama mazhab berbeda pendapat tetapi juga bersepakat pada syarat umum bagi para pihak yang melakukan akad hawâlah yakni bahwa para pihak cakap melakukan perbuatan hukum (balig dan berakal sehat).

- Ji'âlah adalah jenis akad untuk suatu manfaat materi yang diduga kuat dapat diperoleh. Misalkan seseorang melakukan akad ji'âlah untuk suatu pekerjaan yang ia dianggap mampu melakukannya, seperti dapat mengembalikan barang yang hilang, pembuatan dinding, menggali sumur sampai ada airnya, menghafalkan anak seseorang dengan Alquran, diminta menyembuhkan (mengobati) orang sakit sampai sembuh, atau ia dapat menang dalam kompetisi tertentu.

- Qardh, adalah pemberian harta kepada orang lain yang dapat ditagih atau diminta kembali tanpa mengharapkan imbalan. Dalam fikih, akad ini dimasukkan dalam akad tolong menolong (ta'awwuni) dan bukan komersial.23 Dalam lembaga keuangan syariah, khususnya perbankan, qardh digunakan untuk membantu keuangan nasabah secara cepat dan berjangka pendek, membantu usaha kecil dan keperluan sosial. Dana yang dialokasikan untuk qardh, dapat bersumber dari zakat, infak dan sedekah serta sumber-sumber pendapatan yang diragukan kehalalannya.

- Rahn, secara bahasa diartikan al-tsubût wa al-dawâm (tetap dan kekal). Sebagian ulamâ luhgât memberi arti alhab (tertahan).24 Sedangkan definisi al-rahn menurut istilah ialah menjadikan suatu benda yang mempunyai nilai harta dalam pandangan syara' untuk kepercayaan suatu utang, sehingga memungkinkan mengambil seluruh atau sebagian utang dari benda itu.25 Istilah rahn menurut Imam Ibn Mandûr diartikan apa-apa 
yang diberikan sebagai jaminan atas suatu manfaat barang yang diagunkannya. Sedangkan dari kalangan ulama Mazhab Mâlikî mendefinisikan rahn sebagai harta yang dijadikan pemiliknya sebagai jaminan hutang yang bersifat mengikat. Ulama mazhab Hanâfî mendefinisikannya dengan menjadikan suatu barang sebagai jaminan terhadap hak (piutang) yang mungkin dijadikan sebagai pembayar hak tersebut, baik seluruhnya maupun sebagiannya. Ulama Syâfi'î dan Hambalî dalam arti akad, menjadikan materi (barang) sebagai jaminan utang, yang dapat dijadikan pembayar utang apabila orang yang berhutang tidak bisa mem bayar hutangnya.27 Menurut sebagian besar (jumhûr) ulama, rukun rahn terdiri dari orang yang menggadaikan (al-rahn), barang-barang yang digadai (marhûn), orang yang menerima gadai (murtahin) sesuatu yang karenanya diadakan gadai yakni harga, dan sifat akad rahn. 28 Dan untuk sahnya akad rahn ada beberapa syarat yang harus dipenuhi oleh para pihak yang terlibat dalam akad rahn (gadai) yakni berakal, baligh, barang yang dijadikan jaminan ada pada saat akad, serta barang jaminan dipegang oleh orang yang menerima gadai (marhûn) atau yang mewakilinya.29 Dengan terpenuhinya syarat-syarat di atas, maka akad rahn dapat dilakukan karena kejelasan akan râhin, murtahin dan marhûn merupakan keharusan dalam akad rahn. Sedangkan mengenai kapan penggunaan akad rahn diperbolehkan, Alquran dan al-Sunnah serta para ulama tidak menetapkan secara jelas mengenai akad-akad atau transaksi jual beli yang diperbolehkan untuk menggunakan rahn. Ada sebagian kecil ulama, sebagaimana yang dikemukakan Ibn Rusyd (Bidâyah al-Mujtahid) bahwa mazhab Mâlikî beranggapan bahwa gadai itu dapat dilakukan pada segala macam harga dan pada semua macam jual beli, kecuali jual beli mata uang, dan pokok modal pada salam yang berkaitan dengan tanggungan. Hal ini disebabkan karena pada sharf disyaratkan tunai, begitu pula harta modal pada salam. 30 Dari perbedaan pendapat di atas, dapat diartikan bahwa sebagian ulama beranggapan bahwa rahn dapat digunakan pada transaksi dan akad jual beli yang bermacam-macam, walaupun ada perbedaan ulama mengenai waktu dan pemanfaatan dari barang yang dijadikan jaminan tersebut. Benda rahn yang digadai dalam konsep fikih merupakan amanat yang ada pada murtahin yang harus selalu dijaga dengan sebaik-baiknya. Untuk menjaga serta merawat agar benda (barang) gadai tersebut tetap baik maka diperlukan biaya perawatan, yang dibebankan kepada orang yang menggadai, atau dengan memanfaatkan barang gadai tersebut. Dalam hal pemanfaatan barang gadai ini, beberapa ulama berbeda pendapat karena masalah ini sangat berkaitan erat dengan hakikat barang gadai, yang hanya berfungsi sebagai jaminan utang yang dipegang oleh penerima gadai.

- al-Ujr. Ujr merupakan imbalan yang diberikan atau diminta atas suatu pekerjaan yang dilakukan.

4) Akad mumalah yang berprinsip titipan (wadîah) Wadîah merupakan titipan murni dari satu pihak ke pihak lain, baik individu maupun badan hukum yang harus dijaga dan dikembalikan kapan saja penitip menghendaki. Pada dasarnya, penerima simpanan yad alamânah, tidak bertanggung jawab atas kehilangan dan kerusakan pada aset titipan selama bukan akibat dari kelalaiannya dalam memelihara barang titipan, namun dalam aktifitas ekonomi modern, penerima titipan menggunakannya untuk aktifitas ekonomi tertentu. Oleh karena itu, ia harus meminta izin pada si pemberi titipan dengan jaminan akan 
mengembalikannya dengan utuh sehingga penerima titipan bukan lagi yad al-amânah namun yad aldhamânah, yang bertanggung jawab atas segala kehilangan/kerusakan yang terjadi pada barang tersebut.

\section{H. Langkah-langkah Pengembangan Produk Perbankan Syariah}

Dari banyaknya akad yang digunakan perbankan syariah sebagaimana dijelaskan di atas, terbuka peluang bagi bank syariah untuk semaksimal mungkin memberikan produk yang dibutuhkan masyarakat. Ini dapat dilakukan dengan mengaplikasikan langkah-langkah sebagai berikut:

a) Rekonsepsi akad-akad pada bank syariah

Rekonsepsi pemahaman terhadap akad-akad muamalah yang digunakan perbankan syariah menjadi hal yang sangat penting untuk dilakukan. Terutama ketika ketertarikan masyarakat pada perbankan syariah dan keuangan Islam. Akhir-akhir ini menjadi semakin kuat sehingga menuntut pemahaman yang komprehensip bagi para praktisi dan akademisi tentang akad-akad dan pengembangan produk dari akad yang ada. Sebagaimana banyak ditawarkan oleh para pemerhati keuangan syariah melalui mengembangkan akad dengan memadukan berbagai akad yang ada, bahkan melakukan dua akad dalam satu transaksi yang sering disebut dengan hibryd kontrak. Pemahaman yang berkembang dalam pengembangan akad yang diwakili oleh model hibryd kontrak dianggap menjadi salah satu pilar penting untuk menciptakan produk perbankan dan keuangan syariah dalam menjawab tuntutan kebutuhan masyarakat modern. Hal ini dikarenakan bentuk akad tunggal dianggap sudah tidak mampu merespon transaksi keuangan kontemporer. Metode hybrid contracy menurut Mabid alJahri seharusnya menjadi unggulan dalam pengembangan produk. Namun masalahnya, adalah literatur ekonomi syariah yang ada di Indonesia sudah lama mengembangkan teori bahwa syariah tidak membolehkan dua akad dalam satu transaksi akad (two in one), sehingga menyempitkan pengembangan produk bank syariah. Padahal syariah mem bolehkannya dalam ruang lingkup yang sangat luas. 33 Terlepas dari berbagai tawaran pengembangan akad sehingga melahirkan pengembang produk perbankan syariah, yang lebih penting untuk dilakukan adalah pemahaman tentang hakikat akad-akad dalam fikih dan langkah penting dalam melihat relasi antara masyarakat dan lembaga perbankan sebagai lembaga intermediasi.

b) Optimalisasi peran Dewan Pengawas Syariah (DPS)

Merujuk pada Surat Keputusan DSN No. 3 tahun 2000, dijelaskan bahwa Dewan Pengawas Syariah (DPS) adalah bagian dari Lembaga Keuangan Syariah (LKS), dimana penempatan DPS atas persetujuan DSN dengan fungsi DPS meliputi: a. Melakukan pengawasan secara periodik pada LKS yang berada di bawah pengawasannya

c) Berkewajiban mengajukan usul-usul pengembangan LKS kepada pimpinan lembaga yang bersangkutan dan kepada DSN

d) Melaporkan perkembangan produk dan operasional LKS yang diawasinya kepada DSN sekurang-kurangnya 2 (dua) kali dalam 1 (satu) tahun anggaran.

e) Merumuskan permasalahanpermasalahan yang memerlukan pembahasan DSN.34 Senada dengan DSN MUI, pada Pasal 47 PBI Nomor 11/33/PBI/2009 Tentang Pelaksanaan: Good Corporate Governance Bagi 
Bank Umum Syariah dan Unit Usaha Syariah, menjelaskan bahwa tugas dan tanggung jawab DPS adalah memberikan nasihat dan saran kepada Direksi serta mengawasi kegiatan Bank agar sesuai dengan Prinsip Syariah. Sedangkan tugas dan tanggung jawab DPS meliputi antara lain:

- Menilai dan memastikan pemenuhan Prinsip Syariah atas pedoman operasional dan produk yang dikeluarkan Bank

- Mengawasi proses pengembangan produk baru Bank agar sesuai dengan fatwa

- Meminta fatwa kepada DSN-MUI untuk produk baru Bank yang belum ada fatwanya

- Melakukan review secara berkala atas pemenuhan prinsip syariah terhadap mekanisme penghimpunan dana dan penyaluran dana serta pelayanan jasa Bank

- Meminta data dan informasi terkait dengan aspek syariah dari satuan kerja Bank dalam rangka pelaksanaan tugasnya.35 DPS adalah perwakilan DSN pada a DPS-DSN

Lembaga keuangan dan bisnis syariah dalam rangka mengefektifkan peran pengawasan DSN. Oleh karena itu, peran DPS dan DSN bukan hanya mengawasi operasional lembaga keuangan syariah saja, tetapi memiliki peran yang lebih penting yakni berkewajiban mengajukan usul-usul pengembangan produk kepada pimpinan lembaga yang bersangkutan dan kepada DSN sebagimana tercantum dalam fungsi dan tugas DPS, sehingga turut men dorong tumbuh kembangnya ekonomi dan perbankan syariah di Indonesia. Selain sebagai pengawas, Dewan Pengawas Syariah juga berperan sebagai advisor, yaitu pemberi nasehat, inspirasi, pemikiran, saran serta konsultasi untuk pengembangan produk dan jasa yang inovatif untuk persaingan global. Sebagai marketer, yaitu menjadi mitra strategis untuk peningkatan kuantitas dan kualitas industri LKS melalui komunikasi massa untuk memberikan motivasi, penjelasan dan edukasi publik sebagai penyiapan SDM, dan peran strategis lainnya dalam bentuk hubungan kemasyarakatan (public relationship). Sebagai supporter, yaitu pemberi berbagai support dan dukungan baik networking, pemikiran, motivasi, doa dan lainnya untuk pengembangan perbankan dan ekonomi syariah. Sebagai player, yaitu sebagai pemain dan pelaku ekonomi syariah baik sebagai pemilik, pengelola, nasabah penyimpan/investor maupun mitra/nasabah penyaluran dan pembiayaan. Belum optimalnya peran DPS di perbankan syariah sering dihubungkan dengan kualitas dan kinerja DPS yang dianggap kurang memahami sistem dan mekanisme operasional perbankan syariah, karena DPS ditempatkan hanya dalam kapasitasnya sebagai ulama yang memiliki kharisma dan ahli dalam ilmu fikih saja. Kriteria utama untuk menjadi Dewan Pengawas Syariah tidak cukup hanya mengandalkan kemampuan fikih muamalah saja secara normatif, tetapi juga harus memiliki pengetahuan dalam bidang keuangan dan sistem perbankan secara bersamaan karena tugas dan fungsi DPS menuntut kemampuan DPS untuk mampu mengembangkan produk perbankan syariah.

Potensi sosial ekonomi masyarakat Perkembangan perbankan syariah pada praktiknya akan menjadi lebih kompleks, terkait dengan fungsi bank sebagai lembaga intermediasi yang mengumpulkan dana dari masyarakat dan menyalurkannya kembali kepada masyarakat. Kehadiran bank syariah pada dasarnya bermaksud untuk menjawab kebutuhan masyarakat akan adanya pelayanan perbankan yang bebas dari unsur ribâwi yang secara jelas dilarang oleh Islam serta adanya realitas kebutuhan ekonomi yang tumbuh di tengah-tengah masyarakat yang begitu pesat. Adanya bank syariah memberikan pilihan bagi masyarakat untuk memperoleh pembiayaan yang tidak hanya bergantung pada satu jenis bank dengan produkproduknya, namun masyarakat bebas memilih lembaga dan produk mana yang paling sesuai dengan kapasitas yang dimiliki dan kondisi usaha yang dijalankan. Pada prinsipnya, jika bank syariah peka membaca kebutuhan masyarakat berdasarkan 
pada kondisi geografis, dan mampu mempetakan

kebutuhan masyarakat berdasarkan sumber pendapatan masyarakat pada wilayah tersebut, maka pengembangan produk perbankan untuk memenuhi kebutuhan pada masing-masing daerah akan berbeda. Kebutuhan masyarakat Bandar Lampung yang mayoritas penduduknya pegawai dan wiraswasta misalnya, akan berbeda dengan kebutuhan masyarakat Lampung Barat yang mayoritas penduduknya bekerja di sektor pertanian, sehingga sudah semestinya produk perbankan syariah yang ditawarkan di Bandar Lampung akan berbeda dengan produk perbankan syariah di Lampung Barat. Jika kepekaan membaca potensi wilayah dan kebutuhan penduduk tersebut telah dimiliki perbankan syariah, maka pengembangan produk perbankan syariah menjadi satu keniscayaan bagi bank syariah yang ada di wilayah tersebut agar mampu menjawab kebutuhan masyarakat. Selain itu, tingkat persaingan antar bank syariah akan semakin kompetitif dengan mekanisme yang fair, sehingga meminimalisir "pencaplokan" nasabah antar bank syariah yang satu dengan bank syariah lain, karena masing-masing bank syariah akan memiliki produk khusus pada tiaptiap wilayah yang berbeda. Kondisi ini dapat terjadi tidak terlepas dari dukungan DPS yang harus aktif dan inovatif serta berada pada masing-masing bank yang ada di daerah. Di samping itu, bank syariah juga dituntut untuk berani merangkul dan berinvestasi pada sektor usaha yang banyak hidup di masyarakat, baik berupa usaha-usaha perindustrian, pertanian maupun peternakan sesuai dengan kondisi masyarakat dan kondisi geografis wilayah tersebut. Dengan mekanisme ini, perbankan syariah akan mampu mewujudkan apa yang diharapkan masyarakat dan pemerintah, yakni agar lembaga perbankan ikut berperan aktif dalam memacu pertumbuhan ekonomi dan meningkatkan kesejahteraan di masyarakat.

\section{PENUTUP}

\section{A. KESIMPULAN}

Dilihat dari berbagai literatur, perjanjian (akad) terdiri dari beraneka bentuk. Para fuqaha mengelompokkannya berbeda- i.beda sesuai dengan pemikiran mereka masing-masing. Perjanjian (akad) secara khusus adalah perikatan yang ditetapkan dengan ijab dan qabul berdasarkan ketentuan syara yang berdampak pada objeknya. Denga demikian, ijab dan qabul adalah adalah suatu perbuatan atau pernyataan untuk menunjukkan suatu keridhaan dalam berakad di antara dua orang atau lebih. Berdasarkan pengertian di atas, dapat disimpulkan bahwa yang dimaksud dengan akad adalah suatu yang sengaja dilakukan oleh kedua belah pihak berdasarkan persetujuan masing-masing. Dari peristiwa itulah maka timbul suatu hubungan antara dua orang tersebut yang dinamakan perikatan. Sedangkan perikatan adalah suatu perhubungan hukum antara dua orang atau dua pihak, berdasarkan mana pihak yang satu berhak menuntut sesuatu hal dari pihak yang lain, dan pihak yang lain berkewaji ban untuk memenuhi tuntutan itu. Keberadaan akad memiliki peranan yang krusial dalam lapangan muamalah dengan banyaknya implikasi yang ditimbulkan. Salah satunya adalah bahwa dalam Islam terdapat kebebasan untuk melakukan akad dengan menentukan segenap syarat para pihak yang melakukannya. Karena itu, pendekatan berbasis akad ini akan digunakan untuk mendalami dan menganalisis kesesuaian akadakad muamalah itu dengan konsep akad dalam persfektif hukum Islam.

\section{B. SARAN}

Saran yang bisa penulis berikan :

Perlu adanya metode yang lebih lanjut akan upaya peningkatan dikusi terhadap pembaca sebagai salah satu cara memaksimalakan potensi genarasi dalam membentengi dirinya dari radikalisme agama yang berkembang. 


\section{REFERENSI}

Abdurohman, D. (2020). Kontrak/Akad Dalam Keuangan Syariah. Jurnal EcoBankers: Jurnal Perbankan Syariah, 1(1), 39-58. http://journal.bungabangsacirebon.ac.id/i ndex.php/EcoBankers/article/view/72

Ghofur, R. (2015). Konstruksi Akad Dalam Pengembangan Produk Perbankan Syariah Di Indonesia. Al-'Adalah, 12(3), 493-506.

Kristianto, D. (2012). Implikasi Akuntansi Syariah dan Asuransi Syariah dalam Lembaga Keuangan Syariah. Jurnal Akuntansi Dan Sistem Teknologi Informasi, 7(1), 61-68.

v. M. buyanov. (1967). 済無No Title No Title No Title. Angewandte Chemie

International Edition, 6(11), 951-952. 